\title{
The water footprint of beef cattle in the amazon region, Brazil
}

\section{Urandi João Rodrigues Junior ${ }^{1^{*}}$ (i) Maurício Dziedzic ${ }^{2}$ (D)}

${ }^{1}$ Instituto de Ciências e Tecnologia das Águas (ICTA), Universidade Federal do Oeste do Pará (UFOPA), 68040-470, Santarém, PA, Brasil. E-mail: urandi.rodrigues@ufopa.edu.br. "Corresponding author.

${ }^{2}$ Programa de Pós-graduação em Meio Ambiente, Universidade Ceuma (UNICEUMA), São Luís, MA, Brasil.

ABSTRACT: Food production and water scarcity, both in constant growth and intrinsically linked, are subjects of great relevance in current studies in several areas of knowledge. The impacts generated by the production of beef are at the center of major environmental debates, especially the consumption of water for the production and development of the livestock production chain. This research analyzed the use of

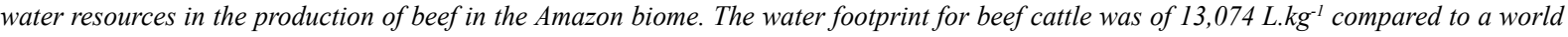
average of $21,829 \mathrm{~L}_{\mathrm{kg}}{ }^{-1}$. Based on the data obtained it was possible to demonstrate that the presence and operationalization of this production chain in the Amazon is more efficient from the water point of view than in the other locations reported in the literature.

Key words: water resources, agribusiness, environmental management.

A pegada hídrica da cadeia produtiva da pecuária na região amazônica

RESUMO: A produção de alimentos e a escassez hídrica, em constante crescimento e intrinsecamente ligadas, são temas de grande relevância em estudos atuais em diversas áreas do conhecimento. Os impactos gerados pela produção de carne bovina estão no centro dos principais debates ambientais, especialmente o consumo de água para a produção e desenvolvimento da cadeia produtiva da pecuária. Este trabalho teve como objetivo analisar o uso de recursos hidricos na produção de carne bovina no bioma Amazônia. A pegada hídrica para bovinos de corte foi de 13.074 L.kg-1, comparada a uma média mundial de 21.829 L.kg-1. Com base nos dados obtidos, foi possível demonstrar que a presença e operacionalização dessa cadeia produtiva na Amazônia é mais eficiente do ponto de vista da água do que nos demais locais relatados na literatura.

Palavras-chave: recursos hídricos, agronegócio, gestão ambiental.

\section{INTRODUCTION}

Livestock production is one of the oldest economic activities in Brazil. According to Silva et al. (2012), between the 17th and 18th centuries, the introduction and dissemination of cattle followed population growth in the country. In 2011, the National Confederation of Agriculture and Livestock estimated the Brazilian cattle herd to be 208 million heads, with an importation of 5,262 heads (live), and an exportation of 1.5 million tons of meat. According to the Ministry of Agriculture (2015), Brazil currently possesses the second largest herd in the world, and since 2004 is the largest beef exporter, representing $20 \%$ of globally commercialized meat supply, with an effective presence in 180 countries. Approximately $84 \%$ of beef produced in Brazil is destined for domestic consumption, and by 2018 it is estimated that $60 \%$ of all beef consumed globally will originate from Brazil (MAPA, 2015). This production chain occupies $20 \%$ of the total area of the country (174 million hectares). Approximately $95 \%$ of the herd are pasture cattle, according to the Brazilian Beef Exporters Association (2015).

According to FAO (2012), farming uses $70 \%$ of the water in Brazil, and about $50 \%$ of this is lost through poor irrigation practices. The National System of Sanitation Information (Snis), points out that about 7 trillion liters of water per year are used for agriculture, and about 3 trillion liters are lost. Koç (2013) reported losses in crop irrigation in several regions of the planet: $35-70 \%$ in the Mediterranean, $80 \%$ in Yemen, $72 \%$ in Thailand, $74 \%$ in Mexico, 50\% in Cyprus and Israel, and between 20 and $70 \%$ in the USA. 
According to FAO (2017), Brazil is among the ten countries with the largest irrigated area in the world. The world leaders are China and India, with approximately 70 million hectares (Mha) each, followed by the USA (26.7 Mha). FAO (2017) estimates that around $70 \%$ of the world's water supply in the irrigated perimeters is lost through evaporation or percolation and without improved efficiency measures, agricultural water consumption is expected to increase by about $20 \%$ globally by 2050 (WWAP, 2016).

Tools that assist the management of water resources can help identify how to diminish these impacts and still allow socioeconomic development. The water footprint is an internationally recognized indicator for its efficiency and replicable method for such purposes, including farming activities.

Employing the water footprint method, Mekonnen et al. (2010) arrived at a global average of $15,000 \mathrm{~L}^{\mathrm{kg}}{ }^{-1}$ for beef production. Hoesktra (2012) showed that between 15,500 and 22,000 L.kg-1 are necessary, data similar to the results presented by Drastig et al. (2010) and Matlock et al. (2013). Mekonnen \& Hoekstra (2011 affirm that 29\% of the total water footprint of farming products in the world pertain to animal activities and $1 / 3$ of this are related to beef cattle.

The research reported herein was to measure the water footprint of the beef productive chain, adapting the tool to the research area's productive reality, as recommended in the Water Footprint Manual (HOESKTRA et al., 2011). It has been shown that the water footprint of farming activities varies largely between countries and farming systems (CHAPAGAIN, 2003). Studies employing this methodology that focus on the beef production chain are relatively rare, compared to the large number of works concerning grain and industrialized products. Studies examining the water footprint of dairy cattle include Ridoutt et al. (2010) conducted in Australia, and Zonderland-Thomassen et al. (2012) conducted in New Zealand. In Brazil, Palhares (2011) considered the dairy cattle production chain. Mendonça et al. (2010) estimated the water footprint of beef production in both pastoral and nonpastoral systems in Brazil.

Although, several researches exist on the subject, such as those reported by Mekonnen (2011), Palhares (2015), Morelli (2013), and Mendonça (2010), there are many limitations often involved in calculating the water footprint.

At this point, it should be noted that the present research adopted the classical approach developed by Hoekstra et al. (2011), known as the
Water Footprint Assessment (WFA), as opposed to the newer approach based on life cycle assessment (LCA) and summarized as an ISO standard, viz. ISO 14046 (ISO, 2014). These approaches have been compared by Manzardo et al. (2016), who concluded that they can lead to consistent results in terms of hotspot analysis, but not in terms of degradative uses (BRAGAGLIO et al., 2018 and DICK et. al 2015). The novel characteristic of the present research is its focus on the Amazon region, and its use on actual field data.

The present study evaluated two areas whose development is linked to the advance of beef cattle raising in the country. These areas lay in the Amazon Basin that holds $73.6 \%$ of available water in Brazil. According to the National WaterAgency (ANA, 2007), water destined for the beef production chain in Brazil represents $11 \%$ of all water consumption in the country, or $177.37 \mathrm{~m}^{3} \cdot \mathrm{s}^{-1}$. Data from the Remote Sensor Center of the Universidade Federal of Minas Gerais CSR-UFMG (2014) indicated that the Brazilian cattle herd grew $60 \%$ between 1987 and 2013, while the herd in the Amazonian States (Mato Grosso, Pará, Acre, Rondônia, Roraima, Amazonas, Tocantins, Amapá, and Maranhão) practically tripled (280\%), representing 80.7 million heads, circa $35 \%$ of the national total. According to the Brazilian Institute of Geography and Statistics (IBGE, 2014), the state of Mato Grosso accounts for $13 \%$ of the national total, while the state of Pará has $9 \%$, with a combined total of approximately 48 million heads of cattle. The region near the research areas has approximately 600 thousand heads (IBGE, 2014).

\section{MATERIALS AND METHODS}

\section{Scope and fieldwork}

The first step in the production chain is pasture development. Its water footprint was estimated following the recommendation of Hoekstra (2011), considering null the blue water footprint, since no irrigation is necessary. The gray water footprint was null, since no fertilizer is used in this type of crop, and thus does not reach the water bodies, as pointed out by Hoesktra (2012). The second step in the chain is cattle breeding itself, and the water footprint here includes water consumed by cattle and water used for general services such as cleaning. The third step in the chain concerns the slaughtering and processing of meat involved in production (refrigeration, tanning, etc.), and the fourth step involves retail and consumption. The present research measured the water footprint of the processes that occur inside the 
farm, i.e., the first and second step. This choice of scope is allowed within the water footprint model and is based on logistic and operational issues related to the study areas and the many possible variations in steps 3 and 4 .

Two areas were selected for analysis, one in the state of Pará, and the other in the state of Mato Grosso. Their choice was dictated by local geographic dimensions, logistics, and access to information from the producers. The two areas are $1,250 \mathrm{~km}$ apart, and are representative of typical beef cattle farms in the region.

Both areas were investigated employing the same methods of data collection. After contact was established with the farm owner, an exploratory visit was conducted, the area was mapped, interviews were conducted, a report was prepared and discussed with the farm owner.

\section{Research areas}

For research area 1 (Figure 1), a farm located in the municipality of Alenquer, in the western region of Pará, was selected. It is a private property, where beef cattle has been raised for more than 30 years. Two visits were conducted, on 21/03/2015 and 28/12/2015. The farm consists of 104 hectares of pasture and at the time it held 350 heads of cattle (3.3 heads.ha ${ }^{-1}$ ).

For research area 2 (Figure 2), a farm located in the municipality of Novo Mundo in Mato Grosso was selected. This private property is located $40 \mathrm{~km}$ from the city center, with 890 hectares in total, 450 hectares of which are used for pasture to raise beef cattle. The owner had over 20 years of experience, and at the time of the visit 1550 heads of cattle $\left(3,4\right.$ heads.ha $\left.{ }^{-1}\right)$. The area was visited on $30 / 10 / 2015$ and two visits were made to the farm's office (06/11/2015 e 12/11/2015) located in Sinop, Mato Grosso, approximately $250 \mathrm{~km}$ from the area.

The type of cattle raising adopted throughout most of the country and also in the specific areas of research is pasture grazing. In 2012 only $1.9 \%$ of the Brazilian beef herd was raised confined (ANC, 2013). The remainder occupy 172 million hectares of pastures throughout the country, with $22 \%$ of the national herd (IBGE, 2014) reported in the region analyzed.

Step 1 of the production chain is growing pasture. The pasture green water footprint was estimated following Hoekstra (2011)

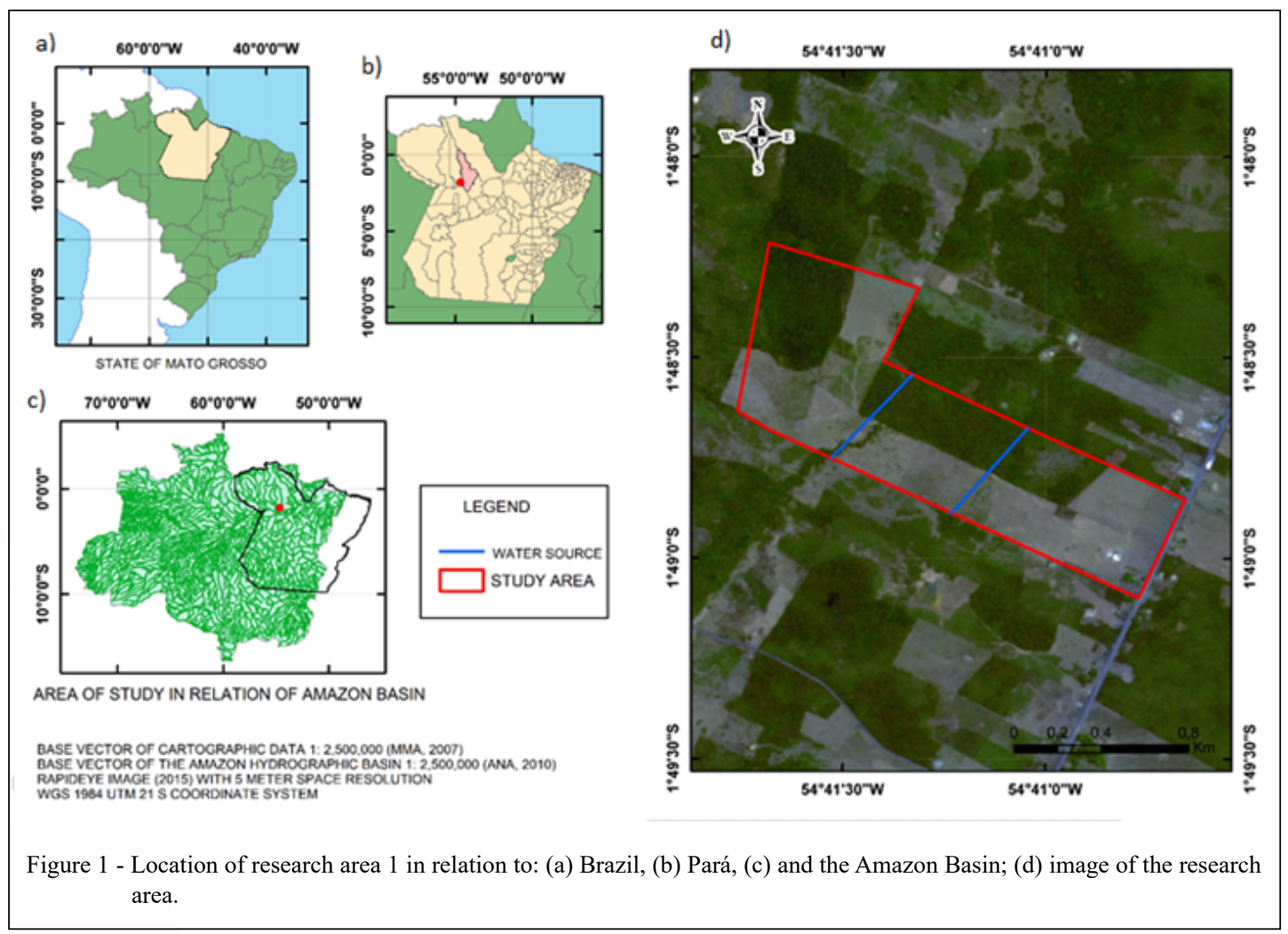

Ciência Rural, v.51, n.8, 2021. 

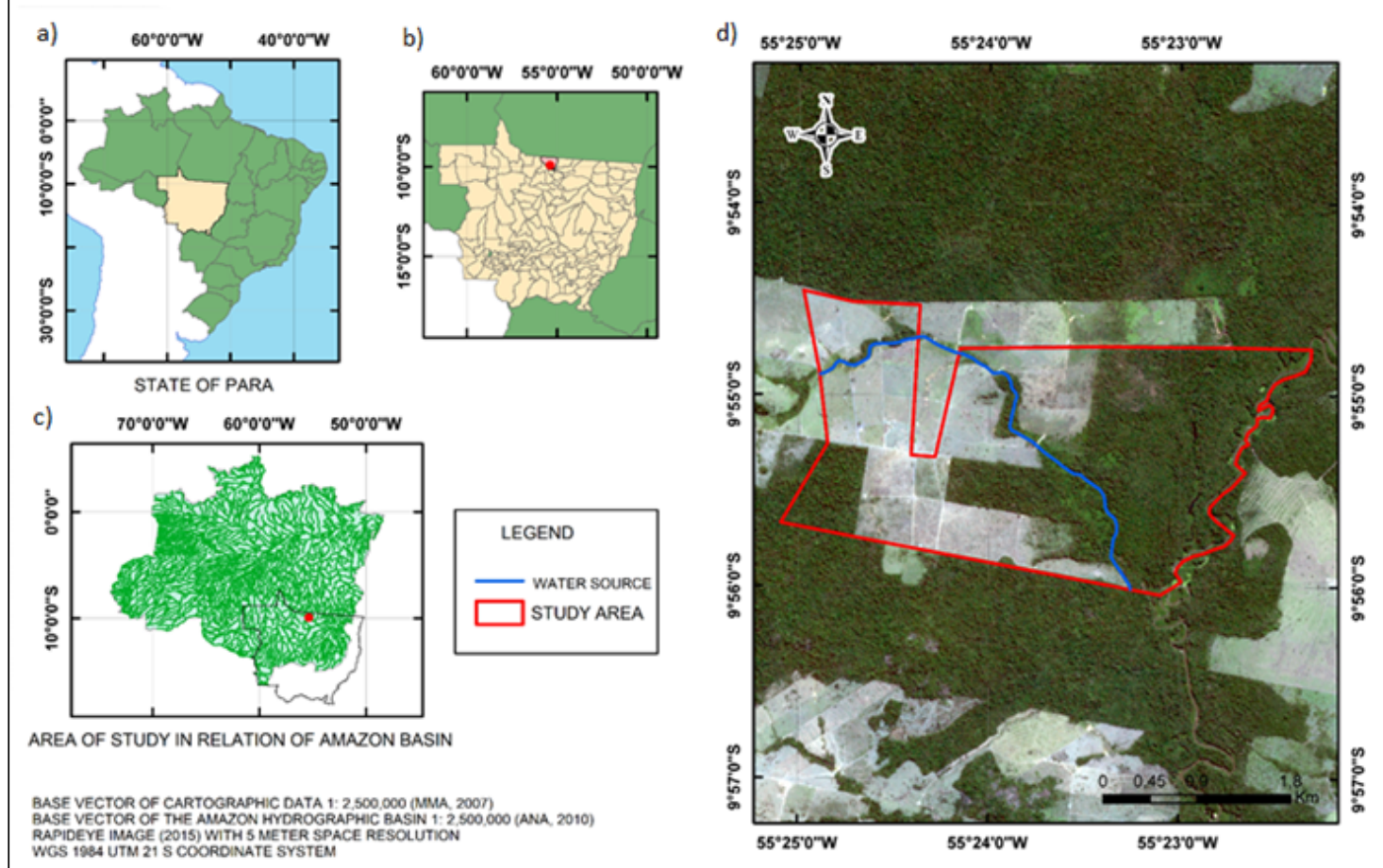

Figure 2 - Location of research area 2 in relation to: (a) Brazil (b) Mato Grosso (c) and the Amazon Basin; (d) image of the research area.

recommendation, the blue water footprint was considered null since the cultivated areas do not use irrigation in their production process. The grey water footprint resulted null, since no fertilizer is used in this kind of culture, and little animal waste, if any, reaches the water bodies, as pointed out by Hoesktra (2012). Step 2 is the cattle raising itself, and the water footprint here includes the water consumed by the cattle and the water used for general services, such as cleaning. Step 3 of the beef production chain concerns slaughter and the meat processing involved in the production (refrigeration, tanneries, etc.), while step 4 involves retail and consumption. The present research measured the water footprint of the processes that occur inside the farm (steps 1 and 2).

In addition to the field data, secondary data was gathered from the literature and technical reports (The Brazilian Agricultural Research Corporation EMBRAPA, Association of Mato Grosso Breeders ACRIMAT, and Ministry of Agriculture, Livestock, and Supply - MAPA). The calculation of the water footprint followed the methodology presented by Hoekstra et al. (2011), synthesized by equation 1 $W F_{\text {total }}=W F_{\text {green }+} W F_{\text {blue }+} W F_{\text {grey }}$
Where:

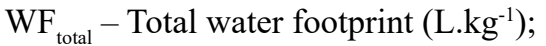

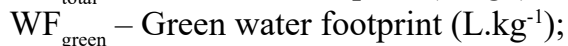

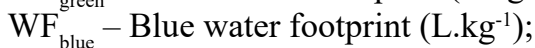

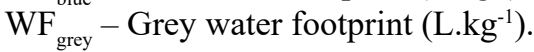

The calculation of the green water footprint of pasture cultivation considered the data listed in table 1 , and included the use of the software CROPWAT (FAO, 2010) to estimate evapotranspiration. The pasture considered in the study is the Brachiaria, a genus of grass that occupies $80 \%$ of Brazilian pasture areas (QUADROS, 2002) and involves a planting cycle of 90 days.

Since the grass initial growing cycle lasts only 90 days and the production cycle of the beef cattle adopted in this methodology is 1095 days, it was necessary to calculate the green water footprint for the other 1005 days, for grass maintenance. This corresponds to half the daily average evapotranspiration during pasture development, as recommended by CROPWAT (2010) for the cultivation of perennial pastures.

Equation 2 is employed for the calculation of the total green water footprint, and takes into

Ciência Rural, v.51, n.8, 2021. 
Table 1 - Data for the calculation of the green water footprint of pasture (Brachiaria grass) grown for beef cattle grazing.

\begin{tabular}{lc}
\hline DATA & \multicolumn{1}{c}{ SOURCE } \\
\hline AREA SIZE & Farmer \\
EVAPOTRANSPIRATION daily average & CROPWAT \\
Cultivation period & Farmer $/($ VEIGA, 2005) \\
Total days of cultivation & Farmer $/($ VEIGA, 2005) \\
Production Average: pasture per hectare (converted into tons) ${ }^{-1}$ & days \\
\hline
\end{tabular}

account herd composition, i.e., the percentage of bulls and cows.

Total green water footprint $=\mathrm{Qtotal}_{\text {water }}{ }^{*}$ Area / $\left(\right.$ Herd $_{\text {total }}{ }^{*}$ Average mass $\left._{\text {mas }}\right)$

Where:

Qtotal water: Total water (pasture growth and maintenance period) in $\mathrm{m}^{3} \cdot \mathrm{ha}^{-1}$.

Area: total planted area, ha.

Herd $_{\text {total }}:$ Total herd in the area - number of individuals; Average $_{\text {mass }}$ : Average ox body mass, $\mathrm{kg}$.

In order to calculate the grass green water footprint, evapotranspiration data from the software CROPWAT was used. Table 2 shows the data used in the CROPWAT program (FAO, 2012) as a basis for the calculation of the green water footprint in the production of brachiaria used in livestock feed.

The choice of the average soil file is due to the similarity of this FAO model to the predominant soils in the study region, which are red latosol and yellow latosol. An average daily evapotranspiration of 2.82 mm.day ${ }^{-1}$ was obtained, and the total evapotranspiration for the 90-day period was $253.5 \mathrm{~mm}$.

For the calculation of the blue water footprint, bulls and cows were considered separately. After farm visits and interviews with ranchers, it was observed that data on water consumption, mass and development were significantly different for each gender. The herd was divided into three age groups as recommended by Embrapa (2013a) for annual data analysis. Information on water consumption per animal was also obtained in the field. The item liters consumed per kg per day results from the division of the quantity (L) ingested per day by the average mass $(\mathrm{kg})$ of the cattle in each age group.

\section{SWOT analysis}

A strengths, weaknesses, opportunities, and threats (SWOT) analysis was conducted for water use in the farm. The strengths and weaknesses concern internal environmental information of the farm (resources, planning, actions, and strategies). The opportunities and threats are connected to the external environment (market, legislation, politics, economy, and the environment). The evaluation of the questions was based on their relevance and classification. Relevance $(0-100 \%)$ represents how much the information relates to water use management. Classification (1-3) indicates the importance of the item for the management of, or the impact on, water resources in the area. The product of relevance and classification resulted in a single value for each item considered The SWOT analysis was based on field observations and interviews with the farmers. During these interviews, aspects of water use in the process were discussed, without a structured questionnaire, adding qualitative aspects to the data gathered. This allowed the study to include the farmer's view of the process, who felt as active

Table 2 - Data for the calculation of the green water footprint of pasture (Brachiaria grass) grown for beef cattle grazing.

\begin{tabular}{lcc}
\hline DATA & SOURCE & UNIT \\
\hline AREA SIZE & Farmer & ha \\
EVAPOTRANSPIRATION daily average & CROPWAT & $\mathrm{mm}_{\text {.day }}^{-1}$ \\
Cultivation period & Farmer/(VEIGA, 2005) & days \\
Total days of cultivation & Farmer/(VEIGA, 2005) & days \\
Production Average: pasture per hectare (converted into tons) & BALSALOBRE (2008) & $\mathrm{kg}^{-h^{-1}}$ \\
\hline
\end{tabular}

Ciência Rural, v.51, n.8, 2021. 
participants of the research, benefitting from and enriching the results.

\section{Analysis in other areas}

For each biome present in Brazil, a region was selected that has a significant herd size (IBGE, 2015) and the analysis method employed in the present research was also applied.

\section{RESULTS}

\section{Quantitative results - water footprint}

The green water footprint of the study area was 2,537.56 $\mathrm{m}^{3} \cdot \mathrm{ha}^{-1}$ during cultivation (90 days). Following the same procedure, the daily average for maintenance of the grass for the other 1005 days is $1.41 \mathrm{~mm}$.day ${ }^{-1}$, totaling $14,168.03 \mathrm{~m}^{3} \cdot \mathrm{ha}^{-1}$ (pasture maintenance). Thus, the total green water footprint for grass production in the study area was $12.35 \mathrm{~m}^{3} \cdot \mathrm{kg}^{-1}$ of meat produced (live weight), or 12,348.12 L. $\mathrm{kg}^{-1}$.

Water consumption in services was 3000

L.day-1. Water is extracted from underground (artesian wells) and surface (river that flows into the property) sources and used for production-related services such as cleaning. This water extraction, if not managed, can cause several impacts on the environment such as: dewatering / contamination of groundwater, siltation of the riverbed, among others. However, appropriate management minimizes environmental impacts (RODRIGUES, 2004). Dividing this value by herd size ( 350 head) results in 8.57 L.day $^{-1}$ per head of cattle. Multiplying this value by the total livestock cycle (1095 days) results in 9,386 L.cycle ${ }^{-1}$ per animal for both bulls and cows. The total volume of water is $48,727.50 \mathrm{~L}$ for cows and 42,705.00 L for bulls. The blue water footprint is obtained by summing the amount of water used in irrigation services, divided by the final mass of cattle at the time of slaughter. For cows, the value obtained was $161.43 \mathrm{~L} \cdot \mathrm{kg}^{-1}$, while for bulls it was $104.18{\mathrm{~L} . \mathrm{kg}^{-1}}^{-1}$, in live weight. The grey water footprint was observed to be null in this research area. This null value information agrees with the observations of Hoesktra et al. (2012) for the rearing of cattle in pasture systems. The same criteria are adopted by Mendonça et al. (2010) for the rearing of cattle in unmaintained pastures in Brazil.

The total water footprint for beef cattle in area 1 is: $12,452{\mathrm{~L} . \mathrm{kg}^{-1}}^{-1}$ for bulls considering a $500 \mathrm{~kg}$ mass at time of slaughter, $12,509 \mathrm{~L} . \mathrm{kg}^{-1}$ for cows considering a $360 \mathrm{~kg}$ mass at time of slaughter. The slightly higher value for cows is due to the increased water consumption while nursing.
Adopting a similar procedure for research area 2, the green water footprint of grass cultivation was of $2,756.44 \mathrm{~m}^{3} \cdot \mathrm{ha}^{-1}$ for the growing period (90 days) and 15,390.12 $\mathrm{m}^{3} \cdot \mathrm{ha}^{-1}$ for pasture maintenance. The total green water footprint resulted in 13,542.21 L. $\mathrm{kg}^{-1}$ of produced meat.

The consumption of water in services was 7000 L.day $^{-1}$. This volume accounts for cleaning services, and, irrigation of the pastures separated for bulls and sick cows, representing the water extracted from subterranean and surface sources, the same situation as above for bulls. Next, dividing this value by the herd size (1,500 heads) results in 4.67 L.day ${ }^{-1}$ per head of cattle. This is then multiplied by the total rearing cycle (1,095 days) giving 5,110 L.cycle $^{-1}$ for both bulls and cows. Animal watering was calculated at 50,370 L.cycle $^{-1}$ for cows and 42,705 L.cycle ${ }^{-1}$ for bulls. For cows the blue water footprint results in $154.11{\mathrm{~L} . \mathrm{kg}^{-1}}^{-1}$ while for bulls the value is $95.63 \mathrm{~L}^{\mathrm{kg}} \mathrm{kg}^{-1}$. The grey water footprint was also considered null for this area.

Thus, the total water footprint for area 2 is 13,637.84 L.kg-1 for bulls, and 13,696.30 L.kg-1 for cows, with an average of $13,667.08 \mathrm{~L} . \mathrm{kg}^{-1}$.

The average green water footprint of this area is $37 \%$ lower than the global average for pastoral systems and $11 \%$ lower than the global average among the three systems (pasture, industrial, and mixed). The blue water footprint is $425{\mathrm{~L} . \mathrm{kg}^{-1}}^{-1}$ less than the global average.

\section{Local analysis of research area 1}

In situ observations revealed that the area follows a pattern of extensive cattle rearing. The farmer reported that cattle feed consists of pasture complemented by a mixture of salt and urea.

Continuous stocking is adopted in the area. It consists of giving the herd unrestricted and uninterrupted access to the entire pasture throughout the grazing season (GALZERANO et al., 2013).

The micro-region where the property is located holds the fourth largest herd in the state (EMBRAPA, 2015) (between 160 and 345 thousand heads) representing $4 \%$ of the entire state. All production is destined for the local markets, refrigeration and abattoirs.

Two large streams cross the property that help water the cattle, and were considered in the blue water footprint. Additionally, water is drawn from an artesian well to water some of the cattle and to provide drinking water for the farm. Cattle access to streams impact the water course mostly by the pressure exerted on the edges during watering. According to 
the farmer, the herd always goes in a group to drink, and trample the area.

Water from the stream and the well are used for watering and other services, while pasture cultivation depends on precipitation water only.

\section{Local analysis of research area 2}

The area follows a pattern of extensive cattle rearing. Rotational stocking, adopted by the farmer, is a grazing method that interposes periods of rest and grazing by creating two or more subdivisions (paddocks) in a pasture. Area 2 hosts more animals than area 1 , which requires more careful management. The area is located in a region that is favorable to livestock, which holds about $20 \%$ of the state's cattle (IMEA, 2010). Large refrigeration centers are nearby, which, according to Schlesinger (2009), perform between 300 and 2,000 slaughters per day, as confirmed by the farmer, who reported that his cattle is exclusively sold to abattoirs.

The water use system is more complex than that reported in area 1 due to water availability and the number of animals. On the farm a stream divides the area and is used for watering. In addition, the area has three large above-ground tanks one for sick animals, one for animals separated for technical reasons (bulls of greater financial value, for example), and one cows in the early lactation period with their calves. These drinking holes are always full and fed by artesian wells as well as nearby reservoirs. The farm contains six large reservoirs that hold rainfall and support cattle watering. These reservoirs are reported in pasture areas and were constructed as the herd grew. According to the farmer, the reservoirs normally meet the area's demand, but during occasional droughts subterranean water extraction is necessary. The reservoirs are protected by surrounding vegetation and by preventing cattle access.

The Nhandú river is located at one of the property's borders. This river is part of the Cristalino State Park, a state conservation unit of 185,000 hectares considered one of the most important conservation units in the entire Amazonian region (FEMA, 2002). The farmer reported that the herd does not have access to the river, nor is any of its water used for the farm. The average distance from the pasture area to the river is $1.5 \mathrm{~km}$.

In short, rainfall patterns support a productive pasture system, and confinement is not necessary.

\section{SWOT analysis}

The SWOT analysis for beef cattle case study areas was conducted through field observations and discussions with the producers. The strong points highlighted the water availability of the area, specifically the two streams and the artesian well that provide sufficient water for all activities linked to beef cattle production. Concerning weak points, the impacts on the streams are highlighted because the cattle have unrestricted access to the water bodies.

For opportunities, the method highlights technical partnerships to increase the water use efficiency and the possibility to implement environmental quality criteria, especially for water resources. Threats include the increased use of pesticides in production, since, according to the farmer, their use is gradually increasing due to the continuous emergence of pests in the grass crop. This would impact the grey water footprint.

Opportunities show the possibility of technical partnerships to increase resource use efficiency. Also highlighted is the implementation of environmental criteria, demanded by the majority of international and national customers. Strengths include the water availability - specifically the area's six reservoirs and artesian well that support all cattle and human activities. Weaknesses include the farm's proximity to urban areas, which in the case of increased pesticide use could contaminate surface and subterranean water bodies. The farmer stated that he avoids applying certain products that affect crop productivity, but other vulnerabilities in the crop appear that demand other products (fungicides and herbicides).

\section{DISCUSSION}

Since Hoekstra and Mekonnen (2010) reported that approximately 15,400 liters are necessary to produce one kilogram of beef, the topic has become more relevant and drawn attention in various discussions about animal production. According to those authors, the global water footprint for animal production is of 2.4 trillion $\mathrm{m}^{3}$.year ${ }^{-1}$, of which $87 \%$ is green, $6 \%$ blue, and $7 \%$ grey water footprints. From this total, a third is used to produce beef (MEKONNEN \& HOEKSTRA, 2010). This demonstrated the necessity to treat water as a controllable resource within production processes due to its importance and scarcity. Palhares (2015) points out that $11 \%$ of all water used in Brazil is connected to the production of beef (watering and other services). Leão (2012) noted that water accounting, while recent, is not the only tool for controlling water consumption, and can influence water management practices. 
Mekonnen et al. (2010) considered the weighted averages among industrial, mixed (industrial and pasture), and pasture cattle raising systems over the course of three years in which animals were slaughtered to produce $200 \mathrm{~kg}$ of meat each.

The present research showed a discrepancy between the raising system evaluated by Mekonnen et al. (2010) and the models adopted in the areas under study (extensive pastoral systems). The model used in Mekonnen et al. (2010) differs from about $97 \%$ of the Brazilian production areas (ABIEC, 2016). The blue water footprint global average of $550{\mathrm{~L} . \mathrm{kg}^{-1}}^{-1}$ is much larger than the $129{\mathrm{~L} . \mathrm{kg}^{-1}}^{1}$ found here.

The blue water footprint in the research areas comes exclusively from watering and general services, because no irrigation is used to produce the livestock feed. The global average for watering and general services contributes with only $1 \%$ to the total water footprint, and $30 \%$ of the blue water footprint.

In India, which holds $32 \%$ of the global cattle herd (USDA, 2014), the total water footprint is twice the average of that observed here, considering the data from the same rearing system (pasture). In the United States, which has the $4^{\text {th }}$ largest herd in the world (USDA, 2014), and where 35\% of the country's farms raise cattle, the water footprint exceeds by $6,157{\mathrm{~L} . \mathrm{kg}^{-1}}^{-}$in the areas under study, and the blue water footprint is four times larger. This can be explained by considering the differences reported by Serrano et al. (2012) in cattle management: in the American system, hay is used early in the first months of the animal's life. Additionally, during the gestation period, feed is supplemented with nutrients, which does not occur in the research areas. These inputs elevate the blue water footprint of the American system. In Brazil, Mendonça et al. (2010) considered systems with and without pasture management, and Mekonnen et al. (2010) estimated the pasture systems averages. Hoesktra et al. (2012) and Hasanaki et al. (2010) presented the global averages for pasture systems.

Europe holds the $5^{\text {th }}$ largest herd in the world and consumes 7.9 million tons of beef per year (USDA, 2014), with a predominantly industrial (confinement) rearing system.

Values for France, Turkey, Portugal, and Greece were reported by Hoesktra et al. (2004) in one of the first studies to examine the water footprint of animal products. However, the different water footprints were not reported, but only the total, and the split was estimated based on the global averages proposed by Mekonnen et al. (2010): 94\% for green water footprint, $4 \%$ for blue, and $2 \%$ for grey, considering pasture, mixed, and industrial rearing systems. This adaptation was not applied to the results of Russia and the Netherlands, which present the actual values for the three water footprints as reported by Mekonnen et al. (2010). The beef water footprints reported in the Netherlands and France presented significantly smaller values than those reported in the research areas. This is likely due to the greater water use efficiency of the industrial system practiced in these countries.

In Brazil, the beef production chain represents $35 \%$ of all meat production in the country, the poultry production chain $45 \%(13,133$ thousand tons per year), and the pork production chain $12 \%$ $(3,480$ thousand tons per year) (MACHADO, 2014). The beef water footprint of the areas under study here are larger than the global water footprints of other animal products. If one looks at the sum of blue and grey footprints, only, considering the lesser impact of the green water footprint, it is obvious that pig and chicken are more impacting than cattle.

The analysis performed in the research areas was applied to other regions in Brazil to estimate the impacts of beef production in different contexts. These biomes included: the Amazon Rainforest, the largest tropical rain forest in the world; the Pantanal, which is a vast floodplain; the Cerrado (savannah and forests); the Caatinga (semi-arid forests); the Pampas (fields); and the Atlantic Rainforest. The extensive production system, based on the use of forage plants adapted to the regional conditions and the limited use of other inputs is widespread and accounts for practically $98 \%$ of the national cattle production (BNDES, 2006). However, each biome possesses its own characteristics, specifically with respect to rainfall patterns, climate, and herd management. One important example is the pasture occupancy rate, which varies according to the local conditions. This rate refers to the number of animals per hectare of pasture: $1 \mathrm{AU}$ (animal unit) is defined as one animal of $450 \mathrm{~kg}$ live weight (LOPES \& VIEIRA, 1998).

There is considerable variation in occupancy rates across the different regions in Brazil, which influences water use; and therefore, water demand. These differences are determined by the prevailing conditions in each region, viz., climate, soil, and vegetation, and are usually arrived at through historic trial and error until a sustainable occupancy rate is arrived at.

There is considerable variation in the water footprint results of the different Brazilian biomes due to differences in occupancy rates, proportions of cows to bulls, weight at time of slaughter, and climate conditions. Since the occupancy rate was a significant 
factor for these results, three scenarios were considered: a) primary data occupancy rates (producers, rural unions and associations), varies by region; b) average recommended occupancy rates; (EMBRAPA, 2013b), varies by region, according to the weight at time of slaughter; c) maximum occupancy rate observed in the research (area 2) applied to all regions.

Figure 3 shows the results for each biome in Brazil, with the total water footprint of each region in the three proposed scenarios.

It should be noted that the larger the occupancy rate, the smaller the water footprint as a function of productivity per pasture area. In the Caatinga, Pantanal, and Cerrado biomes the results differ considerably when considering the maximum occupancy rate. Several factors influenced the occupancy rate: rainfall patterns, water availability that supports pasture rotation, a large concentration of refrigeration exporters, which significantly increase demand, among other factors.

According to Guedes et al. (2013), the production systems should adapt to the biome conditions, such as integrating the production systems to the local vegetation in order to balance animal production and the environment. This factor predominantly explains the differences between the biomes. The Pantanal has one of the lowest occupancy rates, only $0.4 \mathrm{Au} \cdot \mathrm{ha}^{-1}$, since during most of the year the area is flooded, and an occupancy rate of 3.3 AU.ha- ${ }^{-1}$ would not be feasible. In the Atlantic Rainforest, the occupancy of 0.30 AU.ha $^{-1}$ can be explained by the low availability of pasture areas due to increasing urbanization, and limiting legislation. In the Cerrado, the difference in water footprints may be explained by the combination of high evapotranspiration, 3.75 mm.day ${ }^{-1}$, the second largest among the biomes, and an occupancy rate of 0.77 AU.ha $^{-1}$.

The scenarios considering the various biomes revealed that the productivity of Brazilian beef cattle are determined by the available water sources, with each region varying in management style and production models. The Pantanal producers, for example, know the river and flooding dynamics of the biome, which directly influence their management practices. The farmer in the Caatinga, recognizing the water scarcity of the area, established a smaller occupancy rate than recommended, while in the Amazon, due to the abundant rainfall, the occupancy rate exceeds the recommendation and the productivity tends to be larger. The occupancy rate in Brazil can

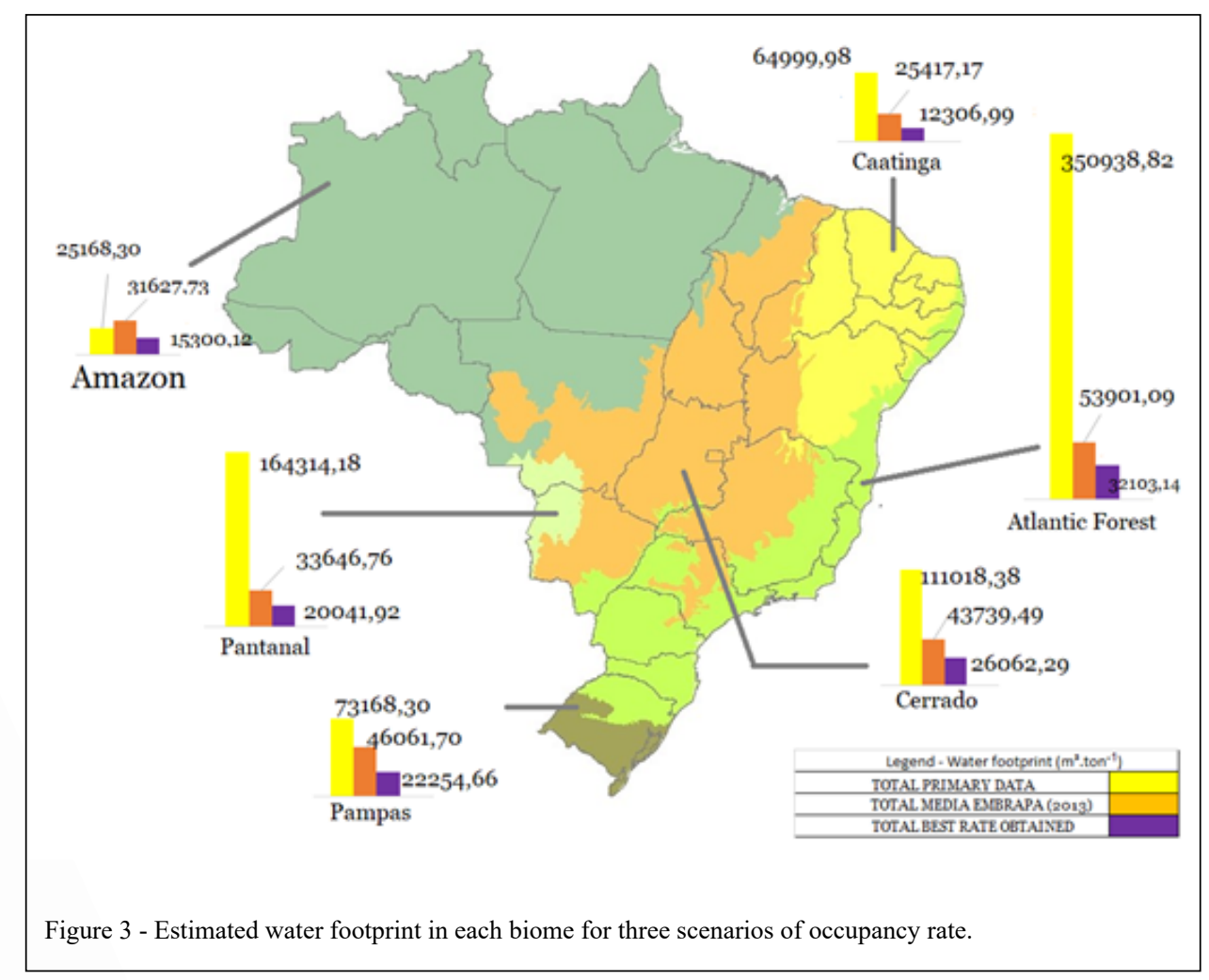

Ciência Rural, v.51, n.8, 2021. 
reach up to $4 \mathrm{AU}^{-h^{-1}}$ in exclusive pasture systems (LUPINACCI,2000), with costs for this system being $0.87 \mathrm{US} \$ . \mathrm{kg}^{-1}$ of meat produced as compared to US\$1.90 $\mathrm{kg}^{-1}$ in the US (ABIEC, 2006).

\section{CONCLUSION}

In general, the water footprint values obtained in the research areas analyzed herein are smaller than most values reported in other studies utilizing the water footprint method. This showed that the current management practices of the production chain, good water use practices, and experience in the various processes contributed to the efficient use of water resources. Morelli et al. (2012) stated that water management should be internalized in the production systems to minimize the risks and optimize water security through more efficient use, and this was verified through interviews with the producers. Palhares (2015) stresses that a large gain in efficiency will come when productive chains incorporate the concept of water management. It is worth mentioning again that the precipitation patterns of the study areas, the choice of grass as the source of nutrition for the cattle, and the pasture management all contributed to such results.

This research considered bulls and cows separately in the analysis, which was not reported in other studies. Weight at slaughter, annual weight gain, and the percentage of the herd were taken into consideration.

It is well known that the Amazon region has suffered negative impacts from the expansion of cattle production such as soil degradation, greenhouse gas (GHG) emissions, and biodiversity loss (BNDES, 2006). Research in various areas has shown that deforestation has occurred mainly by the conversion of forest to cattle production land (ARIMA et al., 2005). For Margulis (2003), deforestation in the region would not have occurred only due to the construction of highways if cattle ranching were not feasible in the region. These arguments are reinforced by increased activity in the region, which represented $10 \%$ of the national herd in 1992 and 20\% in 2010. Currently, about $22 \%$ of the national herd can be found in the region (IBGE, 2014), and the activity generates impacts on water resources affecting some riparian forests that are fundamental for water resources preservation.

The process of integration of livestock farming known as ILPF has been adopted and encouraged in Brazil as a sustainable alternative of production in agribusiness. In the state of Mato Grosso, EMBRAPA (2015) achieved, in one of its ILPF areas, cattle raising productivity rate five times higher than the national average and eight times higher than the state average.
Water governance can also be a step towards sustainable production models. It is a concept in which theoretical and practical paths are proposed and adopted in order to establish an alternative relationship between the governmental level and the social demands managing different interests (CAMPOS et al., 2010). The country faces difficulties related to the creation of basin agencies and the institution of water use fees, and immediate attention could be focused on these issues to improve water governance.

The current study focused on water resources used in the beef production chain, and indicated that the areas analyzed are more efficient when compared to other countries and other regions of Brazil since they have a lower water footprint. However, uses of other resources are not considered, as the SWOT analysis highlights. These results reflect the type of pasture management, the available natural resources, including high precipitation rates, and the use (or not) of subterranean and surface water sources. Furthermore, other relevant factors for these results include the farmer's experience with the precipitation patterns. Technical partnerships were also highlighted to optimize production especially regarding legal and market demands. One such example of legal demand that was verified was that of the slaughterhouses, governed by the TAC's (Conduct Adjustment Decree) signed in the Amazon region in 2009 between the Federal Public Prosecutor and the participants in the livestock production chain, which in 2013 included 120 companies from several sectors in addition to the rural producers. These TAC's bind companies to not purchase animals from properties that cause devastation, deforestation, or that have been occupied by squatters. This encourages producers to seek relevant technology and processes to promote resource efficiency. The research areas are representative of about $14 \%$ of all cattle beef exported from Brazil (ABIEC, 2015) and many of the storage centers are concentrated in the Amazon biome. Thus, as the SWOT analysis highlighted, the producers seek adequate production to cater to this attractive growing market.

An argument can be made to forego the green water footprint, since it is freely available as precipitation, and most of it returns to the water cycle shortly after its use, and focus the analysis on the blue and grey components. In that case, precipitation rich areas, such as those in the Amazon, tend to have much lower water footprints than areas where precipitation is not as abundant.

Table 3 synthesizes the results of the main publications that applied the water footprint methodology to beef cattle, indicating each type 
Table 3 - Results presented in other publications using the water footprint methodology for beef cattle compared to the present research.

\begin{tabular}{|c|c|c|c|c|c|c|c|c|}
\hline Research / Author & $\begin{array}{l}\text { Production } \\
\text { system }\end{array}$ & $\begin{array}{l}\text { Green } \\
\text { water } \\
\text { footprint } \\
\quad(\mathrm{L})\end{array}$ & $\begin{array}{l}\text { Blue water } \\
\text { footprint } \\
\text { (L) }\end{array}$ & $\begin{array}{l}\text { Grey water } \\
\text { footprint } \\
\text { (L) }\end{array}$ & $\begin{array}{l}\text { TOTAL } \\
\text { water } \\
\text { footprint }\end{array}$ & $\begin{array}{l}\% \text { Green } \\
\text { part }\end{array}$ & $\begin{array}{l}\% \text { Blue } \\
\text { partl }\end{array}$ & $\begin{array}{c}\% \\
\text { Grey } \\
\text { part }\end{array}$ \\
\hline $\begin{array}{l}\text { Brazil without pasture } \\
\text { management (MENDONÇA } \\
\text { et al. 2010) }\end{array}$ & $\begin{array}{c}\text { Pasture } \\
\text { (without } \\
\text { management) }\end{array}$ & 26,196 & 34 & 0 & 26,230 & $99.9 \%$ & $1.0 \%$ & $0.0 \%$ \\
\hline $\begin{array}{l}\text { India - Hoesktra et al. (2012) } \\
\text { pasture }\end{array}$ & Pasture & 25,913 & 242 & 0 & 26,155 & $99.1 \%$ & $0.9 \%$ & $0.0 \%$ \\
\hline $\begin{array}{l}\text { Brazil (Report } 48 \text { - } 2010 \\
\text { Mekonnen et al. (2010) } \\
\text { pasture }\end{array}$ & Pasture & 23,279 & 150 & 16 & 23,445 & $99.3 \%$ & $0.6 \%$ & $0.1 \%$ \\
\hline $\begin{array}{l}\text { Mundial average (pasture) - } \\
\text { Hoesktra et al. (2012) }\end{array}$ & Pasture & 21,121 & 465 & 243 & 21,829 & $96.8 \%$ & $2.1 \%$ & $1.1 \%$ \\
\hline $\begin{array}{l}\text { USA - Hoesktra et al. (2012) } \\
\text { pasture }\end{array}$ & Pasture & 19,102 & 525 & 590 & 20,217 & $94.5 \%$ & $2.6 \%$ & $2.9 \%$ \\
\hline $\begin{array}{l}\text { Australia (Report } 48 \text { - } 2010 \\
\text { Mekonnen et al. (2010) } \\
\text { pasture }\end{array}$ & Pasture & 18,056 & 745 & 55 & 18,856 & $95.8 \%$ & $4.0 \%$ & $0.3 \%$ \\
\hline $\begin{array}{l}\text { China - Hoesktra et al. } \\
\text { (2012) pasture }\end{array}$ & Pasture & 16,140 & 213 & 0 & 16,353 & $98.7 \%$ & $1.3 \%$ & $0.0 \%$ \\
\hline $\begin{array}{l}\text { Russia (Report } 48 \text { - } 2010 \\
\text { Mekonnen et al. (2010) } \\
\text { pasture }\end{array}$ & Pasture & 15,182 & 411 & 200 & 15,793 & $96.1 \%$ & $2.6 \%$ & $1.3 \%$ \\
\hline $\begin{array}{l}\text { Global Weighted Average } \\
\text { (pasture, industrial and } \\
\text { mixed)- Hoesktra et al. } \\
(2012)\end{array}$ & $\begin{array}{c}\text { Pasture, } \\
\text { Industrial and } \\
\text { Mixed }\end{array}$ & 14,414 & 550 & 451 & 15,415 & $94.0 \%$ & $4.0 \%$ & $2.0 \%$ \\
\hline $\begin{array}{l}\text { Greece Hoekstra and } \\
\text { Chapagain (2004) - Mean } \\
\text { between systems }\end{array}$ & $\begin{array}{c}\text { Pasture, } \\
\text { Industrial and } \\
\text { Mixed }\end{array}$ & 13,979 & 595 & 297 & 14,871 & $94.0 \%$ & $4.0 \%$ & $2.0 \%$ \\
\hline $\begin{array}{l}\text { Portugal Hoekstra and } \\
\text { Chapagain (2004) - Mean } \\
\text { between systems }\end{array}$ & $\begin{array}{c}\text { Pasture, } \\
\text { Industrial and } \\
\text { Mixed }\end{array}$ & 13,356 & 568 & 284 & 14,208 & $94.0 \%$ & $4.0 \%$ & $2.0 \%$ \\
\hline $\begin{array}{l}\text { Area } 2 \text {-Mato Grosso } \\
\text { Average }\end{array}$ & Pasture & 13,542 & 125 & 0 & 13,667 & $99.1 \%$ & $0.9 \%$ & $0.0 \%$ \\
\hline $\begin{array}{l}\text { Brazil with pasture } \\
\text { management (MENDONÇA } \\
\text { et al. 2010) }\end{array}$ & $\begin{array}{l}\text { Pasture (with } \\
\text { management) }\end{array}$ & 12,199 & 34 & 1,107 & 13,340 & $91.4 \%$ & $1.0 \%$ & $8.3 \%$ \\
\hline $\begin{array}{l}\text { Global average between } \\
\text { 1985-1999 Hanasaki et al. } \\
(2010)\end{array}$ & $\begin{array}{c}\text { Pasture, } \\
\text { Industrial and } \\
\text { Mixed }\end{array}$ & 12,410 & 518 & 259 & 12,960 & $94.0 \%$ & $4.0 \%$ & $3.0 \%$ \\
\hline Area 1 - Pará - Average & Pasture & 12,348 & 133 & 0 & 12,481 & $98.9 \%$ & $1.1 \%$ & $0.0 \%$ \\
\hline $\begin{array}{l}\text { Turkey - Hoekstra and } \\
\text { Chapagain (2004) - Average } \\
\text { among systems }\end{array}$ & $\begin{array}{c}\text { Pasture, } \\
\text { Industrial and } \\
\text { Mixed }\end{array}$ & 10,341 & 440 & 220 & 11,001 & $94.0 \%$ & $4.0 \%$ & $2.0 \%$ \\
\hline $\begin{array}{l}\text { France - Hoekstra and } \\
\text { Chapagain (2004) - Average } \\
\text { among systems }\end{array}$ & $\begin{array}{c}\text { Pasture, } \\
\text { Industrial and } \\
\text { Mixed }\end{array}$ & 7,547 & 321 & 161 & 8,029 & $94.0 \%$ & $4.0 \%$ & $2.0 \%$ \\
\hline
\end{tabular}

of water footprint and the cattle raising system. Clear differences can be seen between the results reported here and other publications focusing on other countries and other regions in Brazil. The differences, even with the same methodology, are due to the peculiarities of each site, varying according to the rearing regime (pasture, industrial, and mixed), local water availability (rainfall patterns), which determine the green water footprint, the use of animal supplementation, which increases blue and 
grey water footprints, and the fact that industrial and mixed productions processes use more water, observed in the European countries. Once more it should be emphasized that the present study analyzed only livestock production within the farms and did not consider the water footprint of slaughter and meat distribution.

\section{ACKNOWLEDGEMENTS}

This work was partially funded by the Coordenação de Aperfeiçoamento de Pessoal de Nível Superior (CAPES) Brasil. Maurício Dziedzic thanks Conselho Nacional de Pesquisa e Desenvolvimento (CNPq), Brasil - Finance code 001, for a productivity in research $(\mathrm{PQ})$ grant.

\section{DECLARATION OF CONFLICT OF INTEREST}

The authors declare no conflict of interest. The funding sponsors had no role in the design of the study; in the collection, analyses, or interpretation of data; in the writing of the manuscript, and in the decision to publish the results.

\section{AUTHORS' CONTRIBUTIONS}

The work reported herein results from Urandi João Rodrigues Junior's doctoral research under Maurício Dziedzic's supervision. Both authors contributed to the manuscript, critically revised it, and approved of the final version.

\section{REFERENCES}

ABIEC. Associação brasileira de indústrias exportadores de carne Dados Gerais Pecuária Anuários. Available from: <http://www. abiec.com.br>. Accessed: Dec. 13, 2016.

ABIEC. Associação brasileira de indústrias exportadores de carne. Perfil Pecuária no Brasil. 2015-16 Available from: <http:// www.newsprime.com.br/img/upload2/2016_FolderPerfil_PT $>$. Accessed: Dec. 13, 2016

ANA - AGÊNCIA NACIONAL DE ÁGUAS. GEO Brasil: recursos hídricos: resumo executivo. / Ministério do Meio Ambiente; Agência Nacional de Águas; Programa das Nações Unidas para o Meio Ambiente. Brasília: MMA; 2007. p.60.

ARIMA, E.; BARRETO, P.; BRITO, M. Pecuária na Amazônia: tendências e implicações para a conservação ambiental. Belém: Instituto do Homem e Meio Ambiente da Amazônia, 2005.

BRAGAGLIO, A.; et al. Environmental impacts of Italian beef production: A comparison between different systems. Journal of Cleaner Production, v.172, January 2018, p.4033-4043. Available from: <https://doi.org/10.1016/j.jclepro.2017.03.078>. Accessed: Jan. 26, 2021. doi: 10.1016/j.jclepro.2017.03.078.

CHAPAGAIN, A. K., HOEKSTRA, A. Y., Virtual water trade. Virtual water flows between nations in relation to trade in livestock and livestock products. 2003. International Expert Meeting on Virtual Water Trade 13(11), p. 1-202.
CSR: Centro de Sensoriamento Remoto, UFMG. Available from: <http: \|maps.csr.ufmg.br.>. Accessed: Jan. 31, 2017.

DRASTIG, K., et al. Water footprint analysis for the assessment of milk production in Brandenburg (Germany). Advances in Geoscience, v.27, p.65-70, 2010, Available from: <https://adgeo. copernicus.org/articles/27/65/2010/adgeo-27-65-2010.pdf $>$. Accessed: Jan. 27, 2021. doi: 10.5194/adgeo-27-65-2010.

DICK, M., DA SILVA, A., DEWES, H. Life cycle assessment of beef cattle production in two typical grassland systems of southern Brazil. Journal of Cleaner Production, v.96, p.426-434, 2015, Available from: <https://www.researchgate.net/publication/269996559 Life cycle_assessment_of_beef_cattle_production_in_two_typical_ grassland systems of southern Brazil >. Accessed: Jan. 26, 2020. doi: 10.1016/j.jclepro.2014.01.080.

EMBRAPA, Água: Desafios para a Sustentabilidade da Agricultura In: Anais do I Seminário da Rede AgroHidro, Rio de Janeiro, 2014

EMBRAPA - EMPRESA BRASILEIRA DE PESQUISA AGROPECUÁRIA. Sistema brasileiro de classificação de solos. 3.ed. Brasília, 2013a. 353p.

EMBRAPA - Empresa Brasileira de Pesquisa Agropecuária Comunicado Técnico 101. 2013b. Brasília: Embrapa Cerrados. Available from: <https://www.infoteca.cnptia.embrapa.br/ bitstream/doc/569854/1/comtec101.pdf>. Accessed: Jul. 28, 2016.

FAO - FOOD AND AGRICULTURE ORGANIZATION OF THE UNITED NATIONS. CROPWAT 8.0 model, Food and Agriculture Organization. Roma, Itália, 2010. Available from: <www.fao.org/nr/ water/infores_databases_cropwat.html>.Accessed: Feb. 3, 2013.

FAO - Food and Agriculture Organization of the United Nations. 2012. The state of food and agriculture 2012. Rome: FAO. Available from: <http://www.fao.org/docrep/017/i3028e/i3028e. pdf>. Accessed: Jul. 28, 2016.

Faostat - Statistics Database. Available from: $<$ http://faostat.fao.org $>$. Accessed: Jan. 18, 2016.

Information System on Water and Agriculture - AQUASTAT (2017). Available from: < http://www.fao.org/nr/ water/aquastat/main/index.stm>. Accessed: Aug. 28, 2018.

GALZERANO, L.; et al. Características morfogênicas and estruturas do capim-xaraes submetida a intensidade de pastejo. Arquivo Brasileiro de Medicina Veterinária e Zootecnia, v.34, p.1879-1890, 2013. Available from: <http://www.scielo.br/ scielo.php?script $=$ sci arttext\&pid $=$ S0102-09352015000501343>. Accessed: Jul. 28, 2018. doi: 10.1590/1678-4162-7435.

GUEDES, L.; VALENTE, L. A bovinocultura nos biomas brasileiros. Anais do Evento : 2013. III Simpósio de Sustentabilidade \& Ciência Animal (SISCA), Veterinária e Zootecnia da Universidade de São Paulo (FMVZ/USP) Available from: <http://www.sisca.com.br/>. Accessed: Jan. 27, 2021.

HASANAKI, N., et al. An estimation of global virtual water flow and sources of water withdrawal for major crops and livestock products using a global hydrological model. Journal of Hydrology, v.384, p.232-244, 2010. Available from: <https:// ui.adsabs.harvard.edu/abs/2010JHyd..384..232H>. Accessed: Jul. 28, 2018. doi: 10.1016/j.jhydrol.2009.09.028. 
HOEKSTRA, A. Y., et al., The Water Footprint Assessment Manual. Setting the Global Standard. Earthscan, London, UK, p.228, 2011 .

HOEKSTRA, A. Y., et al. Blue water footprint of agriculture, industry, households and water management in the Netherlands. Water Research Report . 2012, Series No. 58. UNESCO-IHE, Delft, The Netherlands.

IBGE - Instituto Brasileiro de Geografia e Estatística. Brasil em Números. 2014. Available from: $<$ https://biblioteca.ibge.gov. br/visualizacao/periodicos/2/bn_2006_v14.pdf $>$. Accessed: May, $05,2016$.

IBGE - Instituto Brasileiro de Geografia e Estatística . Pesquisa pecuária municipal. In: IBGE. Sidra: sistema IBGE de recuperação automática. Rio de Janeiro, 2015. Available from: <http://www sidra.ibge.gov.br>. Accessed: Aug. 28, 2016.

ISO (International Organization for Standardization). ISO 14046 Water Footprint. Requirements and Guidelines International Organization for Standardization. Geneva, 2014.

MAPA - Ministério da Agricultura Pecuária e Abastecimento. Brasil projeções do agronegócio 2011/2012 a 2021/2022. Brasília: Ministério da Agricultura Pecuária e Abastecimento, 2015. 50p.

MATLOCK, M., et al., Geospatial analysis of potential water use, water stress, and eutrophication impacts from US dairy production, International Dairy Journal, v.31(1), p.S78-S90, 2013. Available from: <http:/www.sciencedirect.com/science/article/pii/ S0958694612001008>. Accessed: Aug. 28, 2017. doi: 10.1016/j. idairyj.2012.05.001

MENDONÇA, F. C.; SANTOS, P. M.; CAVALCANTE, A. C. R. Irrigação de pastagens. In: PIRES, A. V. (Ed.). Bovinocultura de corte. Piracicaba: FEALQ, 2010. p.473-508.

MEKONNEN, M. M., HOEKSTRA, A. Y., A global and highresolution assessment of the green, blue and grey water footprint of wheat. 2010. Hydrol. Earth Syst. Sci. 14 (7),1259-1276. Available from: <https://www.researchgate.net/publication/45492176_A global and high-resolution assessment of the green blue and grey_water_footprint_of_wheat>. Accessed: Aug. 28, 2017. doi: 10.5194/hess-14-1259-2010.
MEKONNEN, M.; HOEKSTRA, A., National Water Footprint Accounts: The Green, Blue and Grey Water Footprint of Production and Consumption, volume 1: Main Report. Value of Water Research Report Series no. 50. UNESCO-IHE Institute for Water Education. 2011 Delft, 44pp. Available from: $<$ http://www. waterfootprint.org/Reports/Report50-NationalWaterFootprintsVol1.pdf $>$. Accessed: Jan. 27, 2021

PALHARES, J. C. P. Desafios hídricos na produção animal. AgroANALYSIS, São Paulo, v.35, n.3, p.26-28, Mar. 2015. ISSN 0100-4298. Available from: <htttp://bibliotecadigital.fgv.br/ojs/index. php/agroanalysis/article/view/51206>. Accessed: Nov. 7, 2016.

PALHARES, J. C. P. Pegada hídrica dos suínos abatidos nos estados da região Centro-Sul do Brasil. Acta Scientiarum. Animal Sciences. Available from: <https://www.scielo.br/pdf/asas/v33n3/a13v33n3. pdf $>$. Accessed: Jul. 28, 2017. doi: 10.4025/actascianimsci.

PALHARES, J. C. P., PEZZOPANE, J. R. M. Water footprint accounting and scarcity indicators of conventional and organic dairy production systems. IV Symposium on Agricultural and Agroindustrial waste Management, 2015. Available from: $<\mathrm{http}: /$ www.sbera.org.br/4sigera/files/3.3_JulioCesarPascalePalhares. pdf $>$. Accessed: Jul. 28, 2017.

RODRIGUES, S. Considerações sobre os Impactos Ambientais da Agricultura Irrigada. Circular Técnica 07 - Julho 2004 EMBRAPA - ISSN 1516-4683.

RIDOUTT, B. G., PFISTER, S. A revised approach to water footprinting to make transparent the impacts of consumption and production on global freshwater scarcity. Global Environmental Change, v.20(1), p.113-120, 2010. Available from: <https:// saiplatform.org/uploads/Library/RidouttPfister-WFalternative-2009. pdf $>$. Accessed: Sep. 13, 2018. doi: 10.1016/j.gloenvcha.2009.08.003.

USDA. United States Department of Agriculture (USDA) USDA Agricultural Projections. 2014. Available from: <http:// www.ers.usda.gov/publications/oce081>. Accessed: Feb. 18, 2016

ZONDERLAND-THOMASSEN, M. A.; LEDGARD, S. F. Water footprinting - A comparison of methods using New Zealand dairy farming as a case study. Agricultural Systems, v.110, p.30-40, 2012. Available from: <https://www.sciencedirect.com/science/ article/abs/pii/S0308521X12000492>. Accessed: Jan. 27, 2021. doi: 10.1016/j.agsy.2012.03.006. 